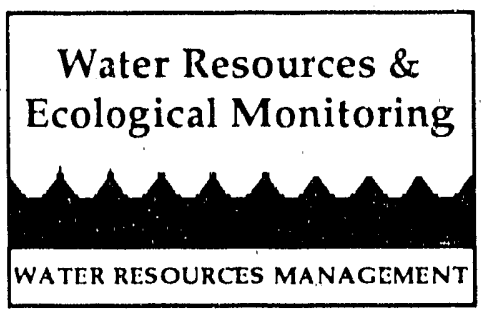

TVA/WR/WQ $--90 / 13$

DE91 005498

\title{
Status of Cherokee Reservoir
}

\section{An Overview of Reservoir Conditions}

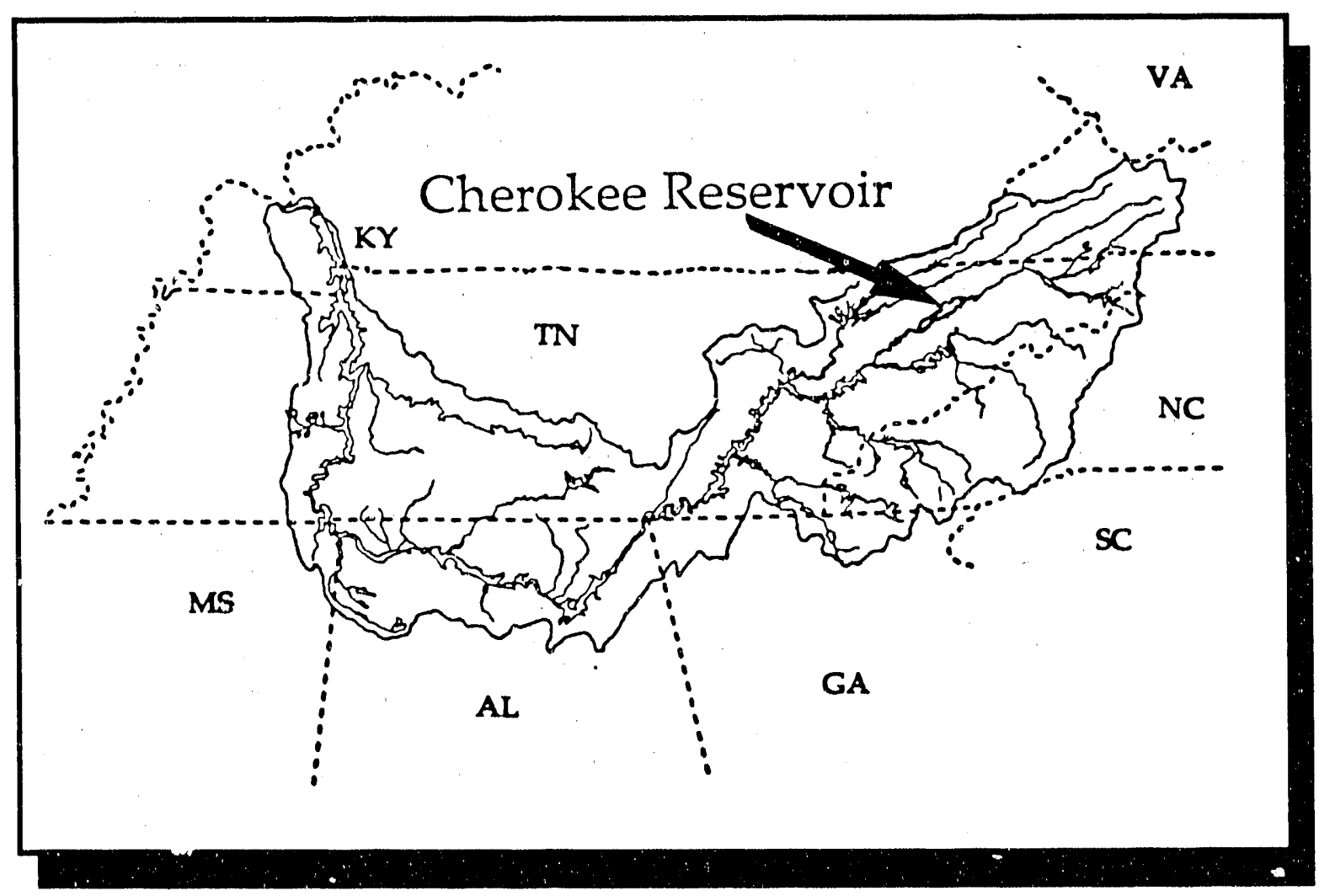

Tennessee Valley Autl ority

Resource Development

River Basin Operations

Water Resources Division

August 1990 
CONTENTS

\section{Page}

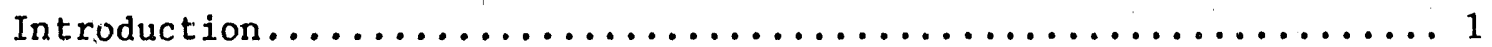

Purpose and Operation of

Cherokee Dam and Reservoir........................... 2

Description of Watershed

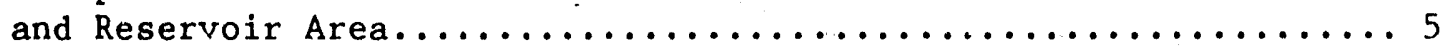

Reservoir Characteristics and Uses..................... 8

Water Quality and Biological Conditions....................

Conditions Affecting Reservoir Uses...................... 24

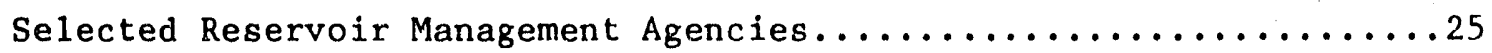

Selected References................................. 
This i

TVA/WR/WQ-90/13

Valley Aut

reservoirs

Tennessee Valley Authority. Water Resources

Division.

and

watershed ,

quality anı

managemen $t$

Chat tanooga, TN

current rel

water resol

agencies ar

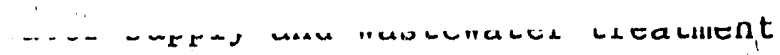

facilities.

Cherokee Reservoir provides many public and private uses for the people of east Tennessee and for overall regional economic growth and development. Operated primarily for flood control, navigation, and power generation, Cherokee is also operated to achieve other beneficial purposes including shoreline development, water supply, water quality, recreation, aquatic and wildlife habitats, and sport fisheries.

Several water quality conditions limit certain of those uses. Low dissolved oxygen levels, in both the hypolimnion of the reservoir and in releases of that water to the stream below the dam, and fluctuations in water level in both the reservoir and tailwater are perhaps the most significant conditions affecting reservoir uses including aquatic life, waste assimilation, recreation, and shoreline development. Other conditions, mainly waste and chemical spills in the Kingsport, Tennessee, area, occasionally affect reservoir uses for water supply and aquatic life. Although many improvements have been made over the years in point source pollution control upstream, similar improvements are needed in the area of nonpoint sources.

Several agencies have a part in improving and protecting the beneficial uses of Cherokee Reservoir including TVA, the Tennessee Department of Health and Environment, and the Tennessee Wildlife Resources Agency. These agencies investigate and monitor the reservoir and attempt to mitigate those conditions impairing its uses. 
PURPOSE AND OPERATION OF CHEROKEE DAM AND RESERVOIR

The Cherokee Dam and Reservoir project completed by TVA in 1941 is located on the Hol-ton River in Jefferson, Grainger, Hamblen, and Hawkins Counties, Tennessee (see centerfold map). Cherokee Dam, at Holston River mile (HRM) 52.3, impounds 54 miles of the Holston River extending upstream to the John Sevier Fossil Plant detention dam at HRM 106.3. In accordance with the purposes established by the TVA Act, the project was built and is operated primarily to control downstream flooding during the rainy winter and spring, to aid downstream navigation during the dry summer and fall, and--whenever it does not interfere with flood control or navigation--to generate electricity. To the extent that there is no conflict with these congressionally mandated objectives, Cherokee Dam is also operated to achieve other beneficial purposes including shoreline development, water supply, water quality, recreation, aquatic and wildife habitats, sport fisheries, and other public and private uses for overall regional economic growth and development.

Navigation benefits are provided to recreational boaters on the reservoir and to help meet commercial navigation requirements on the Tennessee River. Commercial navigation locks are not included at Cherokee Dam. Under normal weather conditions, streamflow to meet navigation requirements is provided for in the operation for flood control and power generation. Under dry weather conditions, special releases are provided for navigation.

Flood storage capacity in Cherokee Reservoir provides significant protection for many locations downstream, especially for the area around Chat tanooga, Tennessee. Cherokee Reservoir, with a storage capacity for flood control of $1,145,900$ acre-feet, is the third largest tributary storage impoundment in the TVA system.

Hydroelectric power is generated by four turbines in Cherokee Dam that have a total installed capacity of 135 megawatts and provide roughly 4 percent of the total. hydropower capacity of the TVA system. Generation is scheduled when seasonal, weekly, or daily power demands are the 
greatest to avoid using more costly sources of power. Because seasonal demands are greatest from June through August and December through February, late winter and spring flows are stored to meet peak power demands of summer. Operations at Cherokee also help regulate inflows to a11 downstream hydroelectric plants on the Tennessee River from Fort Loudoun Dam to Kentucky Dam.

The normal annual operation cycle of Cherokee Dam and Reservoir includes releasing water through the summer and fall to generate hydropower during high summer peaks and to create space for storage of high flows common in winter. Releases vary from zero to 17,000 cubic feet per second (cfs). In early spring, as the risk of floods lessens the reservoir is allowed to fill. It usually reaches its highest level during May or early June. Reservoir filling may be limited for 2 weeks during spring to aid fish spawning. Pool levels can vary by $55 \mathrm{feet}$ during the year depending on rainfall and power demands, but the water level normally fluctuates about 28 feet. In response to growing public pressure, TVA is now considering a proposal to maintain higher, more stable summer lake levels to increase recreation benefits from reservoir operations (TVA 1990).

Special operations are performed at Cherokee Dam each year to accommodate specific needs. For example, releases from Cherokee and Douglas Dams are scheduled as necessary to ensure a minimum daily average flow of 2,000 cfs past Knoxville, Tennessee, for adequate assimilation of treated wastewater discharges as part of the Knoxville-Knox County waste treatment management plan. P.eleases are also scheduled to stabilize reservoir levels during the spring for a 2-week period when reservoir temperature reaches $65^{\circ} \mathrm{F}$ at the 5 -foot depth to provide for fish spawning. In November 1988 TVA initiated a reservoir releases improvement demonstration to provide a minimum flow of 325 cfs for downstream fisheries. 


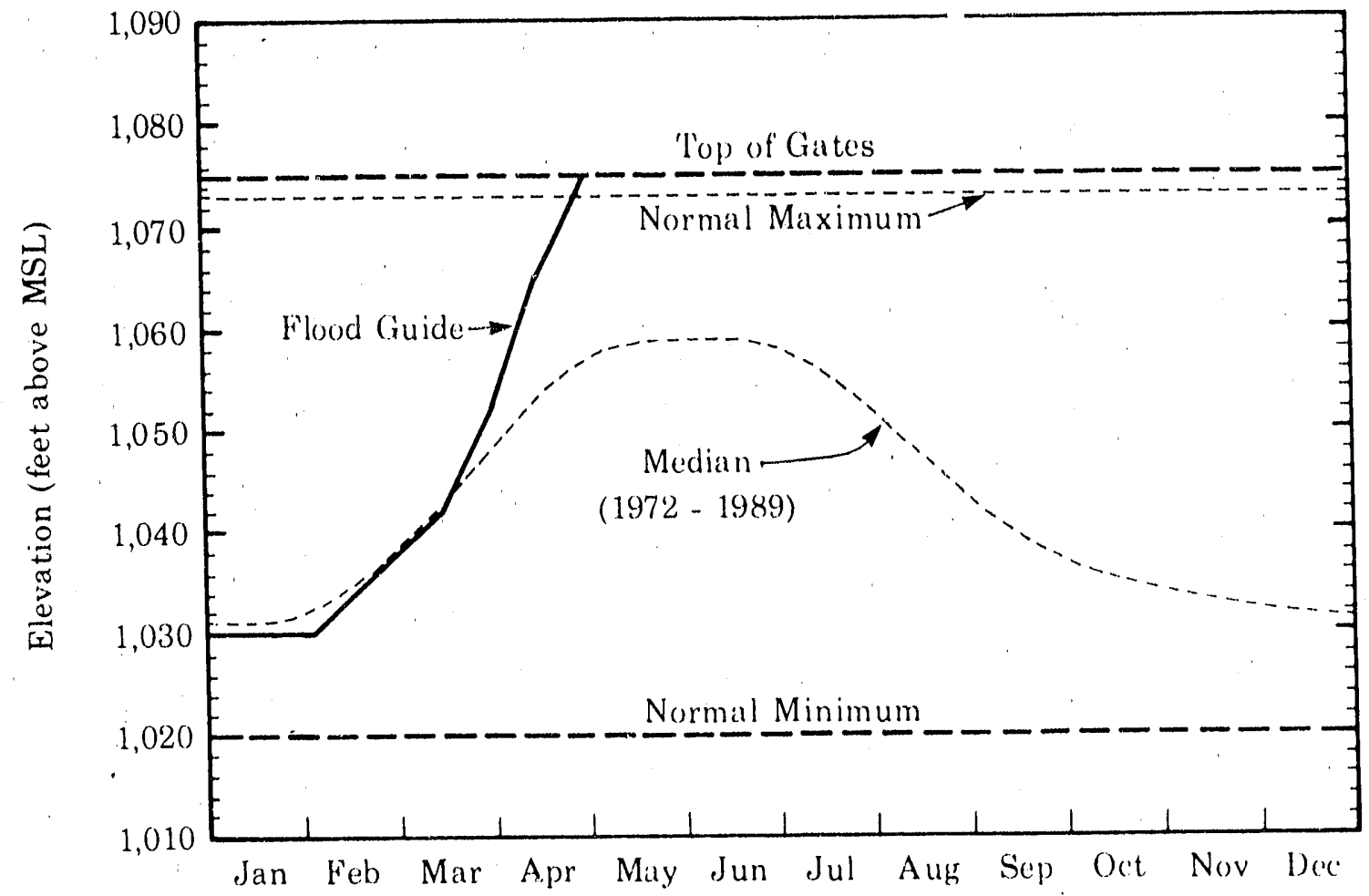

Seasonal and normal maximum and minimum pool clevations of Cherokee Ruservoir 
The Holston River watershed, or drainage basin, above Cherokee Dam covers 3,429 square miles in Virginia, North Carolina, and Tennessee. It is divided into two large subbasins: the unregulated North Fork Holston River (NFHR) basin drains 729 square miles, mostly in Virginia; and the South Fork Holston River (SFHR) basin drains over 2,048 square miles in portions of Virginia, Tennessee, and North Carolina. Five TVA impoundments control runoff from the SFHR basin and tend to serve as barriers between upstream sources of pollution and downstream points of water use: Ft. Patrick Henry, Boone, Wilbur, Watauga, and South Holston. The confluence of the NFHR and the SFHR, 90 miles upstream from Cherokee Dam, forms the Holston River.

The basin upstream of Cherokee Dam and below the confluence of the NFHR and SFHR drains 267 square miles and has one small TVA impoundment formed by a detention dam, which was constructed to provide couling water for the John Sevier Fossil Plant. The impoundment also serves as a catchment basin for suspended pollutants from the NFHR and industrialized Kingsport area. This area consists of more gently rolling hills, much of which is used for agriculture.

Land use in the Holston River watershed consists of about 53 percent forest 1and, 40 percent agricultural land, 4 percent urban development, and 3 percent other uses. The NFHR basin is sparsely populated mountains with steep, forested slopes. The upper portion of the SFHR basin is rugged, forest covered mountains, while the lower portion is more gently rolling hills largely used as pasture for beef and dairy cattle but also for significant urban and industrial development, especially in the Kingsport, Bristol, and Johnson City areas. The extent of agricultural land use when combined with topographic features has potential for substantial nonpoint source pollution (runoff from land uses). Point source contributions (pipe discharge from wastewater source) from the irdustrialized Kingsport area have had a significant impact on water quality in Cherokee Reservoir. 
Annual precipitation averages about 45 inches for the Holston watershed, compared to the Tennessee Valley average of about 51 inches. Annual air and surface water temperatures average about $57^{\circ} \mathrm{F}$. This level of precipitation provides adequate stream flow to support various reservoir uses during the year. However, surface runoff from rainfall. also carries nonpoint source pollutants such as soil particles, minerals, pesticides and herbicides, and plant nutrients (nitrogen and phosphorus), which affect water quality.

The four county Cherokee Reservoir area is paralleled by the clinch Mountains to the northwest and the Great Smoky Mountains to the southeast. Rock formations are sedimentary interbedded 1imestone and shale with extensive folding and faulting. This geology influences the water chemistry of Cherokee Reservoir. In addition, mined zinc deposits in the Jefferson City area have contributed heavy metals, especially zinc and cadmium, to their receiving streams and Cherokee Reservoir.

The reservoir area is experiencing moderate growth and has a 1987 estimated population of 148,900 . Knoxville, 30 miles southwest with a population of 173,210 , is within easy access to the reservoir. The population of an area is an important factor in water quality. It determines the nature of industrial and domestic waste sources and intensity of land use.

Shoreline development, or land use, directly affects the water quality of Cherokee Reservoir. Cherokee Reservoir at full pool has 393 miles of shoreline. In addition, islands in the reservoir have a combined shoreline length of 62 miles. Shorelands range from broad, open fields to steep, wooded bluffs. About 21 miles of privately owned shoreline has been developed for single-family residences, mainly along the lower end of the reservoir from the dam to Highway $25 \mathrm{E}$. Light to moderate residential development exists from Highway $25 \mathrm{E}$ to John Sevier Fossil plant. Many of the homes along the shoreline are served by subsurface sewage disposal systems which, given the geology of the area, may be adversely affecting water quality in localized areas. 
IVA owns about 8,070 acres of 1 and around Cherokee Reservoir above fu11 pool and has flowage easement on about 2,340 acres. F1owage easements allow TVA to flood the land to a certain elevation. Owning land around the reservoir allows TVA to positively influence developinent on adjacent lands by controlling access to the reservoir. TVA owns several large tracts, including a 400-acre tract along Highway 25E and a 700 -acre tract along Highway $11 \mathrm{~W}$ adjacent to Poor Valley Creek embayment. About 4,900 acres of the TVA property is forested, and about. one-third of the total is in tracts smaller than 100 acres.

One unique aspect of Cherokee Reservoir shoreline land management involves outstanding agricultural rights. During the purchase of property for the project in the 1940 's, TVA allowed land owners of many tract to retain the right to use areas not covered by water for agricultura1 purposes so long as it did not interfere with TVA programs. This included the pasturing of livestock and the planting, cultivation, and harvesting of crops. These outstandings rights complicate land ownerships, create problems with titles to the land, especially when subdivided for residential use, and may have a bearing on water quality issues involving animal waste getting into the reservoir.

Recreational facilities include 1 state park, 3 county parks, and 3 TVA pub1ic use areas. There are also 14 commercial docks, 27 public boat ramps, and 829 boat slips. In 1988 , these facilities provided about 1,010 campsites, 140 picnic areas, 1 beach, and 67 lodging units. In addition, a state waterfow1 refuge (John Sevier Waterfow1 Refuge) is located just above the John Sevier detention dam. The Sequoyah Council of the Boy Scouts of America has a 900-acre camp near Morristown. Major recreational facilities are shown on the centerfold map.

There is no industrial development on the reservoir. 
The physical characteristics of Cherokee Reservoir are sunmarized below:

Feature

Location, Holston River mile

Norma1 maximum surface elevation, feet above mean sea level Surface area, acres Volume, acre-feet Maximum depth, feet Average depth, feet Length, miles Shoreline length, miles

Normal minimum surface elevation, feet above mean sea level Surface area, acres Volume, acre-feet

Turbine intake elevations, feet above mean sea level Useful controlled storage volume, acre-feet (E1evation 1075-1020)

Average hydraulic retention time, days
Measurement

52.3 to 106.3

$$
\begin{array}{r}
1,073 \\
30,300 \\
1,481,000 \\
150 \\
50 \\
54 \\
393 \\
1,020 \\
12,300 \\
419,500 \\
944-966 \\
1,145,900
\end{array}
$$

Average month1y inflows vary from about 3,000 cfs in 0 ctober to about $7,000 \mathrm{cfs}$ in February. Of the total inflows, most are from the South Fork Holston River.

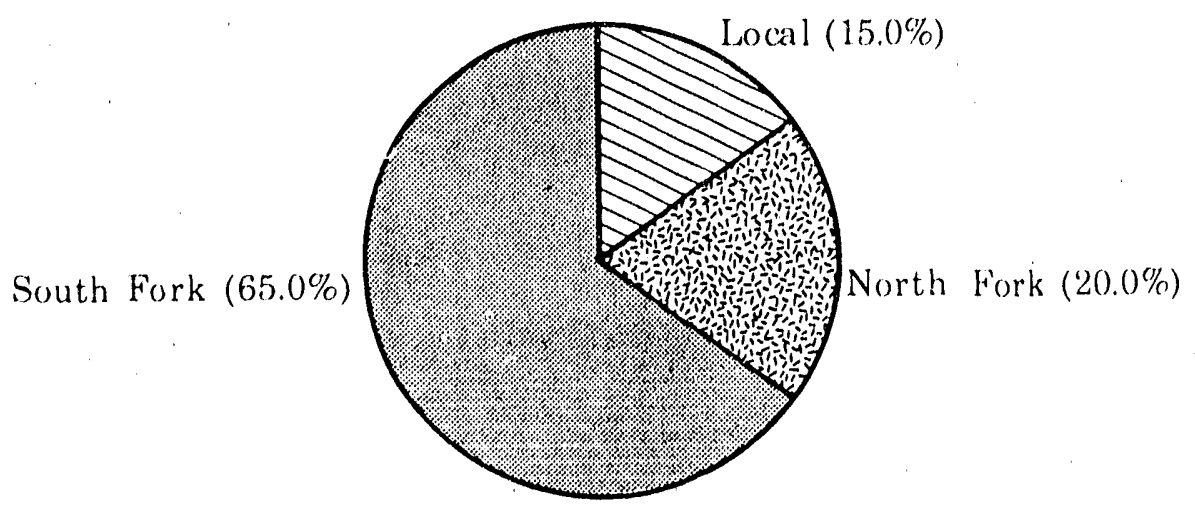

Source and distribution of annual inflows 
Cherokee Reservoir has two large embayments: German Creek embayment. (about 2,700 acres), which behaves much like a separate smal1 reservoir, and Poor Valley Creek embayment (about 500 acres).

Uses of Cherokee Reservoir include not only the primary uses of navigation, flood control, and hydroelectric generation but also such secondary uses as shoreline development, recreation, water supply, habitat for aquatic 1 ife, and sport and commercial fishing. For water quality management purposes, the State of Tennessee has classified the waters of Cherokee Reservoir for domestic water supply, industrial water supply, fish and aquatic life, recreation, irrigation, and livestock watering and wildife. These classifications determine the criteria and standards used in regulating wastewater discharges and determining the acceptability of water quality.

The fishery, and diverse aquatic community of Cherokee Reservoir are the most productive of any reservoir in the TVA system. Cherokee has one of the best black bass fisheries in the Tennessee Valley. Some of the important game fish are largemouth bass, smallmouth bass, bluegill, white bass, and crappie. Catch rate for black bass is good, with about 118,500 caught and 12,000 harvested in 1989. Limited commercial fishing with hoop nets, slat baskets, and trot lines harvests primarily catfish.

Although recreation is not a primary objective of Cherokee Reservoir, expenditures for recreation contribute significantly to the local economy. Increasing recreational use is reflected in the approximately 2,500,000 day-visits in 1986, as compared to 2,200,000 in 1976 . Investments in recreational facilities increased from $\$ 13$ million in 1976 to more than $\$ 26$ mi11ion in 1988 .

Cherokee Reservoir provides a water supply for the city of Morristown. The city has a multilevel water supply intake located at Holston River mile 75.3 to withdraw water from different depths based on the quality of the water. Before construction of the multilevel intake, Morristown experienced difficulty with water withdrawn from the bottom of 
the reservoir because of high leve1s of soluble iron and mangancsc that require special treatment to prevent stains. Morristown currently withdraws about 4,000, n00 gallons per day (mgd).. At present, there are no large industrial wacer supply intakes, and use for agricultural water use is limited and poorly documented.

The principal municipal wastewater discharges to Cherokee Reservoir are listed below. In addition to these, the John Sevier Fossil Plant withdraws $654 \mathrm{mgd}$ of once-through cooling water from the Holston River and discharges it back to the upper end of Cherokee Reservoir.

\section{Discharger}

Rogersville Sewage

Treatment Plant

Morristown Sewage

Treatment Plant

Jefferson City Sewage

Treatment Plant
Discharge location

HRM 99.7

HRM 75

Mossy Creek mile

2.5 to HRM 52.4
Average daily discharge, mgd

0.69

3.0

0.37

Several small sewage treatment plants discharges (for example, Mooresburg Elementary School, Panther Creek State Park, etc.) are located directly on the reservoir or on small tributaries. These facilities discharge a total of $0.07 \mathrm{mgd}$. Some discharges occur at boat docks where moored recreational boats equipped with marine toilets discharge treated or untreai i sewage directly in the reservoir. There are no pump-out facilities on the reservoir for adequate disposal of boat wastes. 
WATER QUALITY AND BIOLOGICAL CONDITIONS

Inflow characteristics and the interactions of physical, chemical, and biological factors determine the water quality of reservoirs. TVA and others corducted extensive investigations of Cherokee Reservoir in the 1970s and early 1980s. Those studies led to development of a reservoir water quality management plan in 1984. The management plan, along with a water resource issues analysis (in preparation), and recent monitoring results form the basis for the following discussion.

Thermal stratification strongly affects water quality and biological conditions in many reservoirs, including Cherokee Reservoir. From late spring through early fall the sun warms surface waters to a greater extent than deeper waters. Because warm water is less dense than cold water, it remains or "floats" on top as a distinct surface layer that does not mix with the colder bottom layer. This separation into two strata or layers of different temperalure and density is thermal stratification. A mid-temperature layer or "thermocline" separates the warm surface layer or "epilimnion" from the deeper, cooler water or "hypolimnion." Strong thermal stratification occurs in Cherokee Reservoir during the summer. In summex, temperatures in the epilimnion range from $72^{\circ} \mathrm{F}$ to $80^{\circ} \mathrm{F}$, while those in the hypolimnion range from $42^{\circ} \mathrm{F}$ to $50^{\circ} \mathrm{F}$. In winter, convection cooling at the surface causes mixing of these layers and temperatures become relatively uniform from the surface to the bottom, averaging about $45^{\circ} \mathrm{F}$.

During strong thermal stratification, microbial and chemical processes in the water and bottom sediments gradually deplete dissolved oxygen in the hypolimnion. In the upper end of the reservoir (HRM 70-90), dissolved uxygen decreases to near zero by late May or early June. Because of the greater volume of the hyrolimnion and other factors, dissolved oxygen is depleted more slowly between HRM 70 and the dan; complete depletion generally does not occur there until late July.

Cherokee has one of the worst oxygen depletion problems in the TVA reservoir system. Annual minimum dissolved o:ygen measurements of 
$0.1 \mathrm{mg} / 1$ in hypolimnetic releases have been recorded ovei a 20 year period in Cherokee Reservoir with no significant detectable trends. Low dissolved oxygen in the hypolimnion reduces habitat for $f$ ish, contributes to periodic mortality of introduced striped bass, and adversely affects bottom-dwelling or benthic organisms.

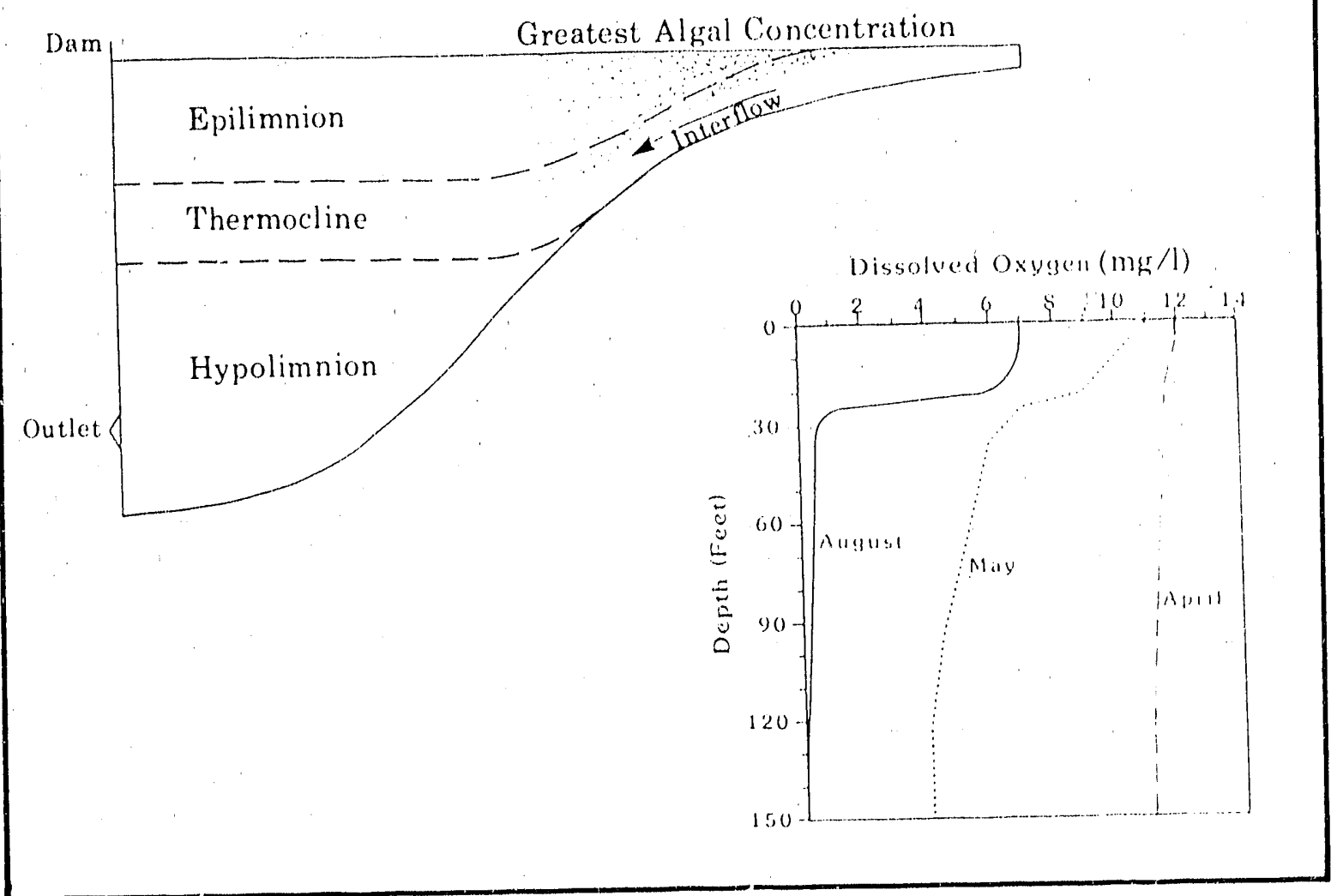

Typicei temperature and disiolved oxygen stratification in Cherokee Rescrvoir

Alkalinity, hardness, and pH values in Cherokee Reservoir indicate relatively hard, well-buffered waters. The $\mathrm{pH}$ value is neutral to slightly basic ( $\left.\mathrm{pH}_{7} 7-8\right)$, except near, the surface, where $\mathrm{pH}$ occasionally approaches 9.0 when photosynthesis by algae removes carbon dioxide and carbonate from the water, thereby reducing the level of carbonic acid and increasing $\mathrm{pH}$. A pH in the range of 6.5 to 8.5 supports a good $\mathrm{fish}$ population. Total hardness caused mainly by calcium and magnesium, derived primarily from the 1 imestone rock that characterizes much of the drainage basin, ranges from 110 to $140 \mathrm{mg} / 1$, which is considered 
relatively hard in this region (on a scale of 1-60, soft; $61-120$, moderate1y hard; 121-180, hard). Alkalinity is a measure of the buffering capacity (ability to receive acids or bases without changing $\mathrm{pH})$ of water. Alkalinity values in Cherokee Reservoir ranged from 75 to $120 \mathrm{mg} / 1$, wilch is within the typical range for surface waters (30-500 mg/1).

Toxic substances are a concern in Cherokee Reservoir because of mercury contamination in fish and sediments of the North Fork Holston River and because of industrial wastewater discharges and accidental chemical spills from the Kingsport area. Recent (1988-89) monitoring. shows a consistent pattern of detectable levels of several heavy metals and synthetic organic compounds in the flesh of fish from both the reservoir and the Holston River upstream, but the concentrations do nct exceed any public health criteria and are not high enough to trig in intensive study. Concentrations of metals in reservoir waters do not pose an immediate threat to reservoir uses. Limited sediment data indicate mercury concentrations increase with depth, attributable to past rt leases from the 01 in Chemical Plant at Saltville, Virginia, which cecs sed operating in 1972 .

Bacteriological quality of Cherokee Reservoir was assessed in 1985. Results at 22 recreation areas indicated excellent bacteriological quality suitable for swimming and other uses, with most values for fecal coliform bacteria less than 10 colonies per $100 \mathrm{~m} 1$. Limited sampling in 1986 at five recreation areas supported earlier results.

Inflows to Cherokee Reservoir come mostly (65 percent) from the South Fork Holston River. Historically, municipal and industrial point source discharges (pipe discharges), especial1y in the Kingsport area, have contributed substantial pollutant loads to the South Fork Holston River. Major wastewater dischargers in the area include Tennessee Eastman Company, Mead Paper Company, and Kingsport Municipal Wastewater Treatment Plant. Holston Army Ammunition Plant, formerly a point source discharger during the Vietnam War, was closed during the early 1970s. This closure, coupled with improved wastewater treatment of other discharges, has 


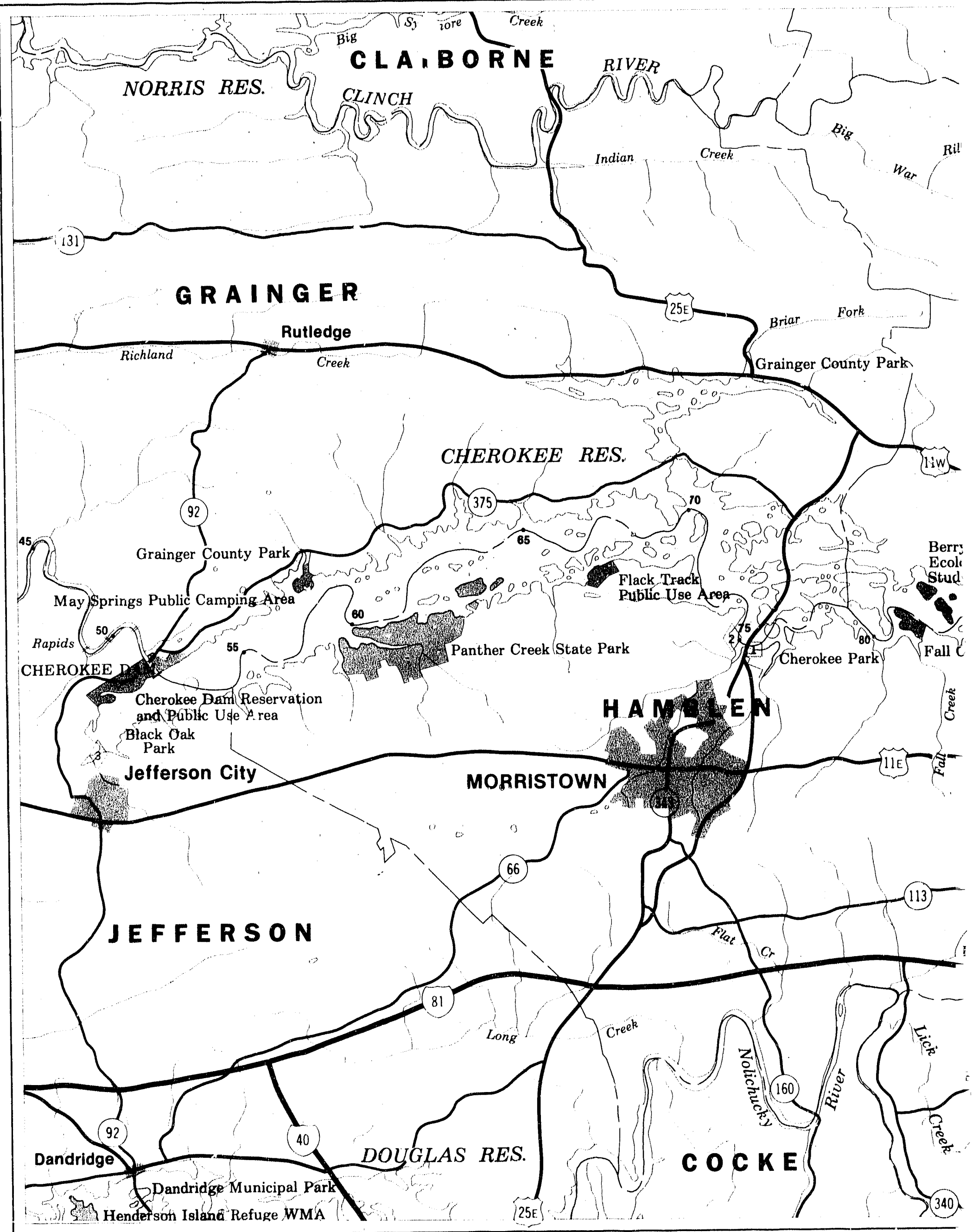




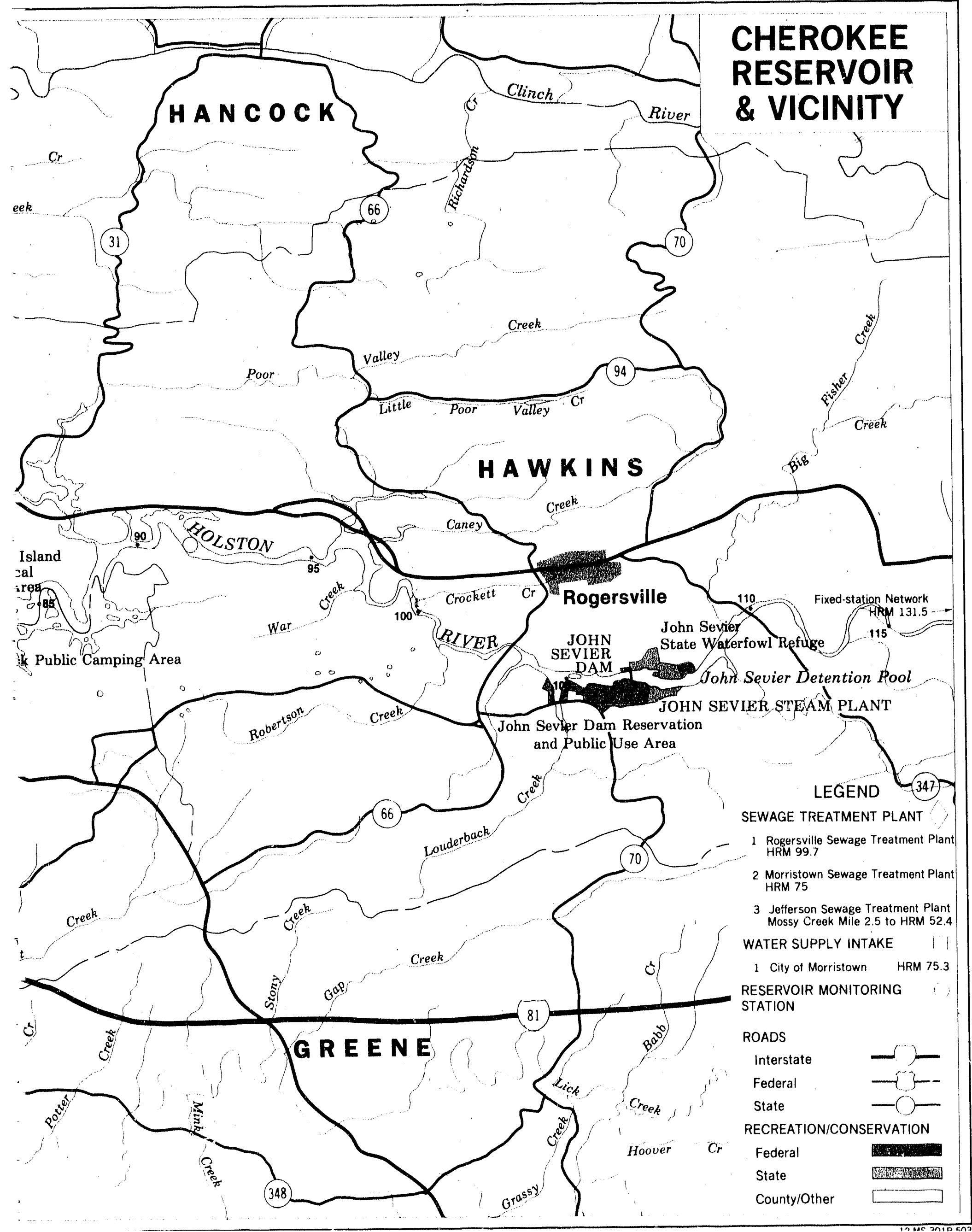


significantly reduced pollutant loadings over the last 2.0 years. However, occasional spills of industrial chemicals and wastes remain a concern. The Holston River above Cherokee Reservuir has experienced several spills of industrial chemicals and wastes, which have killed fish and interfered with recreational use and water supply. The frequency of these spills indicates the need for increased emphasis on spill prevention and control.

Nonpoint source loading can contribute significant pollutant loads. Runoff from agricultural land, livestock operations, construction, and mining operations are examples of nonpoint sources of pollution. Failing septic tanks and commercial and residential development can a!so contribute significant pollutant loadings. Sufficient data are not available to define water quality impacts created by "sse nonpoint sources in the Cherokee Reservoir area. In addition, decaying weed fragments carried into the reservoir from extensive aquatic weed infestations upstream from the headwaters of Cherokee Reservoir to Kingsport, Tennessee, contribute to oxygen depletion during thermal stratification.

Nutrinnts (nitrogen and phosphorus) are important to the biological product $\_$vity of reservoirs. When nutrient loads are excessive, they may produce undesirable conditions including sometimes reducing the aesthetic value and causing economic losses to resort areas because of unsightliness, smell, and fouling of beaches. Nutrient loads from point and nonpoint sources affect the water quality and biological conditions of Cherokee Reservoir. Nonpoint sources have been estimated to contribute as much as 75 percent of the nitrogen and 43 percent of the phosphorous to Cherokee Reservoir. The average nitrogen concentration in the inflow to Cherokee Reservoir is $0.70 \mathrm{mg} / 1$, which is comparable to that in other TVA reservnirs. However, the average phosphorus concentration of $0.14 \mathrm{mg} / 1$ is significantly higher than that for most reservoirs $(0.04 \mathrm{mg} / 1)$. Under favorable conditions of temperature and light, nitrogen and phosphorus have stimulated luxuriant. "blooms" of plankton and caused shifts in the algal community to less desirable species. 
Trophic status as measured by primary or algal productivity ranges from low (oligotrophy) in the down'stream end near the dam to excessive (eutrophy) at the upstream end. Cherokee Reservoir has been ranked as the third most productive or eutrophic tributary reservoir in the TVA system behind Boone and Douglas Reservoirs. This ranking was based primarily on the substantial nitrogen, phosphorus, and chlorophy11 levels existing in the reservoir.

Three overlapping zones of productivity have been observed in Cherokee Reservoir: (1) headwater to HRM 70, (2) HRM 70 to 60 , and (3) HRM 60 to dam. The upper end of Cherokee Reservoir was considered to be highly eutrophic and the lower end meso- to oligotrophic. The increased biological productivity in the upper end of the reservoir is responsible for the enhanced fish production observed in Cherokee Reservoir. Because of low productivity, any new water supplies in Cherokee Reservoir should be liscated in the lower end.

Algae typically have three seasonal peaks. A spring maximum is composed of centric diatoms, cryptomonads, and green flagellates. This gives way to a community dominated by filamentous blue-green algae in summer and early fall. The low winter standing crop consists primarily of diatoms. Many of the summer blue-greens are nitrogen-fixing algae that can convert gaseous nitrogen into a usable nutrient, giving them a competitive advantage during periods when dissolved inorganic nitrogen concentrations in the epilimnion are low. In many reservoirs either nitrogen or phosphorus will be the limiting factor in algal growth, but no single nutrient consistently limits algal growth in Cherokee Reservoir.

Zooplankton', supported by the availability of an abundant food supply of algae, are also abundant. More than 100 difıerent species of zooplankton have been observed in Cherokee Reservoir. These are predominantly rotifers, cladocerans, and copepods, in that order of abundance. 
Turbidity, suspended solids, and clarity vary widely in response to rainfall, runoff, and reservoir productivity. Turbidity, especially when. caused by clay and silt particles, is important in determining light penetration or zone of productivity within the reservoir. When turbidity results from algal concentration, it becomes a measurement of productivity. Water clarity, as measured by Secchi depth, is generally 1 to 2 meters, reflecting the eutrophic status of Cherokee Reservoir and adjacent land use. In the upper end of the reservoir, clarity is seasonally limited by suspended inorganic material such as silt, as well as by algae. In the lower end, the main factor limiting clarity is algae.

The benthic community (bottom-dwelling organisms) has not been adequately surveyed. Cursory examinations in the upper end of the reservoir indicate a scarcity of organisms. Historically, the Holston River supported a diverse and abundant musse1 community. Now musse1 populations in the reservoir are very 1 imited, except for an abundant population of the Asiatic clam (Corbicula fluminea). Low dissolved oxygen, sedimentation, occasional chemical spil1s, and the change in habitat from a river to a lake environment are the probable factors contributing to the present status of the benthic community.

The fish community in Cherokee Reservoir includes 66 species of fishes and two hybrids (striped bass/white bass and walleye/sauger, or saugeye). The average biomass (pounds per acre) of all species of fish combined ovcr the past 50 years is greater in Cherokee than in 20 other reservoirs within the Tennessee Valley and Cumberland River drainage (see following table). A large forage base of gizzard and threadfin shad is available as food for predatory fish. Four coves sampled in 1989 yielded an average of 464 pounds of $\mathrm{fish}$ per acre $(13,550 \mathrm{fish}$ per acre). Game fish (principally bluegill and warmouth, largemouth and sma11mouth bass, and white and black crappie) totaled 167 pounds per acre (5,619 fish per acre). Rough fish (mostly channel catfish, carp, carpsuckers, and drum) totaled 196 pounds per acre (155 fish per acre). Forage fish (largely gizzard and threadfin shad) totaled 100 pounds per acre $(7,776 \mathrm{f}$ ish per acre). 
Number of

Reservoir Inclusive dates samples Game Rough Forage Tota1

\begin{tabular}{|c|c|c|c|c|c|c|c|}
\hline Cherokee & 1949 & -1989 & 106 & 69 & 113 & 607 & 789 \\
\hline Wheeler & 1949 & -1989 & 96 & 110 & 205 & 361 & 676 \\
\hline 01d Hickory & 1957 & -1980 & 30 & 50 & 200 & 302 & 552 \\
\hline Barkley & 1974 & -1983 & 100 & 51 & 182 & 307 & 540 \\
\hline Pickwick & 1949 & -1987 & 67 & 54 & 115 & 217 & 386 \\
\hline Boone & 1953 & -1983 & 31 & 51 & 58 & 245 & 354 \\
\hline Wilson & 1949 & -1983 & 29 & 53 & 132 & 149 & 334 \\
\hline Kentucky & 1949 & -1982 & 105 & 33 & 112 & 156 & 301 \\
\hline Me1ton Hill & 1964 & -1982 & 45 & 20 & 152 & 126 & 298 \\
\hline Guntersville & 1949 & -1988 & 93 & 68 & 82 & 141 & 291 \\
\hline South Holston & 1951 & -1985 & 45 & 58 & 62 & 161 & 281 \\
\hline Ft. Loudoun & 1949 & -1984 & 33 & 43 & 79 & 157 & 279 \\
\hline Chickamauga & 1947 & -1989 & 12.9 & 48 & 78 & 137 & 263 \\
\hline Watts Bar & 1949 & -1986 & 73 & 28 . & 115 & 89 & 232 \\
\hline Douglas & 1949 & -1983 & 37 & $47^{\circ}$ & 103 & 53 & 203 \\
\hline Nickajack & 1972 & -1981 & 22 & 91 & 41 & 88 & 220 \\
\hline Norris & 1949 & -1989 & 101 & 31 & 27 & 108 & 166 \\
\hline Ft. Pat. Henry & 1954 & -1985 & 8 & 19 & 69 & 57 & 145 \\
\hline Watauga & 1949 & -1984 & 38 & 44 & 38 & 57 & 139 \\
\hline Fontana & 1949 & -1984 & 22 & 35 & 30 & 32 & 97 \\
\hline Chatuge & 1953 & -1980 & 18 & 42 & 9 & 7 & 58 \\
\hline
\end{tabular}

Comparison of biomass (pounds per acre) of game, rough, and forage fish in Cherokee Reservoir with 20 other reservoirs in the Tennessee and Cumberland River drainage basins. Data are based on all cove rotenone uamples taken between 1949 and 1989. Boldface values are greater than Cherokee.

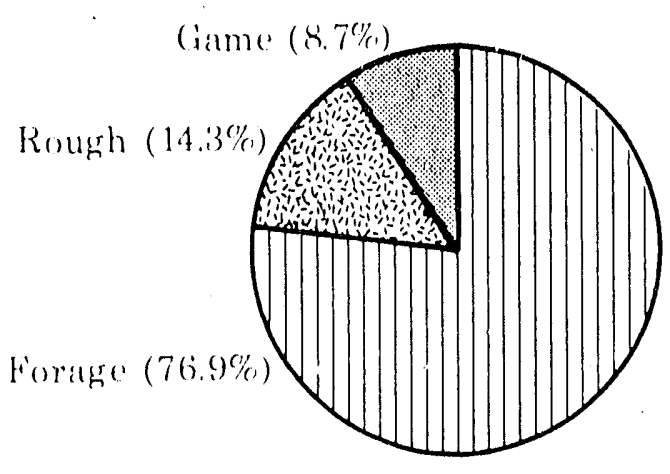

(a)

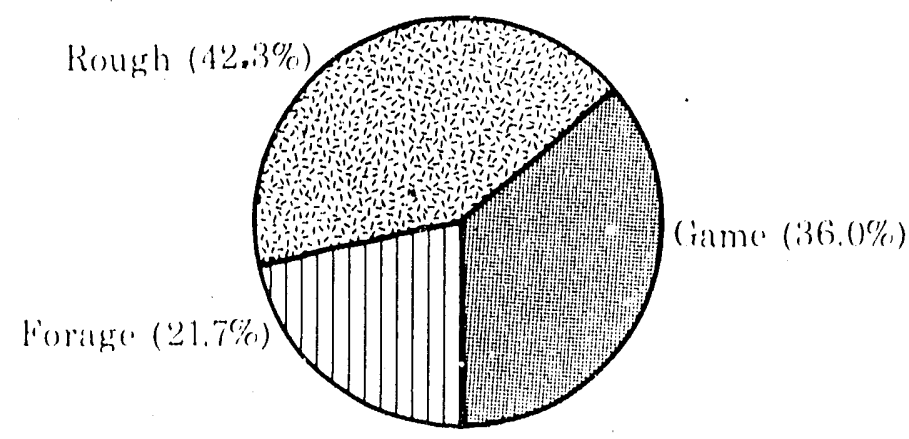

(b)

Mean distribution of fish biomass (pounds per acre) among major groups in Cherokee Reservoir based on (a) 106 cove rotenone samples taken between 1949 and 1989 and (b) 4 cove samples taken in 1989. 
Important game species are monitored annually by the Tennessee Wildife Resources Agency (TWRA) to assess the status of the fishery and provide a basis for management decisions. Management strategins include primarily stocking and imposing size limits. Following is a summary of findings based on the 1989 monitoring program (Peterson and Lane, 1990).

The largemouth bass population is excellent at this time, evidenced by a good spawn in 1989 and a large number of 10 to 12-inch fish that will be contributing to the cree1 in 1990-1991. Based on cree1 results an estimated 118,448 largemouth bass were caught in 1989 , of which 11,826 were harvested or not released. Creeled fish averaged 16 inches and 2.18 pounds. There is, currently, a 15-inch size 1 imit on the black basses. Spring and autumn fish health assessment surveys conducted by TVA in 1989 . indicated largemouth bass in Cherokee Reservoir to be the healthiest of those assessed in 16 reservoirs.

Eight percent of the black basses harvested were smallmouth bass. Average total length was 16.5 inches and average weight was 2.28 pounds. An estimated 10,426 smallmouth bass were caught in 1989, of which 2,800 were harvested.

Spotted bass comprized 2 percent of the black basses creeled in 1989. Spotted bass also comprized 2 percent of the standing stock of black basses in cove rotenone data between 1949 through 1989. They were most abundant in the late 1950's through the 1970's and have declined in abundance throughout the $1980^{\prime} \mathrm{s}$.

White and black crappie populations were very low in 1988 , but a good spawn in 1989 resulted in standing stocks greater than the historical means. Cherokee ranked 10 th in mean standing stock of crappie (white and black combined) among 21 Tennessee Valley reservoirs.

To reverse what appeared to be a declining trend a 10-inch size limit was placed on crappie beginning in March 1989. An estimated 1,545 black crappie were caught in 1989 amounting to 14 percent of al1 crappie 
caught. Six hundred and seventy-six were harvested averaging 10.6 inches in length and 0.32 pounds in weight. An estimated 9,895 white crappie were caught, of which 6,227 were harvested. Mean length of harvested white crappie was 11.2 inches and mean weight was 0.78 pounds. Although higher than in Douglas Reservoir, catch rate is below the average of the remaining reservoirs within Tennessee. TWRA has also proposed to create a crappie nursery in Poor Valley embayment. Fishing would be prohibited in the inundated embayment during the high water spring and early summer. As the water level is lowered, crappie produced in the embayment would be forced out into the main body of the reservoir, where they would be added to the population and potential cree1.

Bluegill and warmouth sunfish had good spawns in 1989. Estimated number of b1uegi11 caught in 1989 was 43,054 with 25,630 harvested.

Estimated total white bass catch was low at 772 with only 241 harvested. Standing stock estimates show a drastic decline throughout the 1980 's with no individuals appearing in the 1989 cove samples.

Striped bass, several years after first being stocked in Cherokee Reservoir, have typically experienced a late summer die-off attributed largely to high temperature and low dissolved oxygen conditions in the reservoir. Most of the striped bass fishery in Cherokee Reservoir occurs during a relatively short time in late sumer, when the fish are concentrated in selected coves that provide suitable water quality conditions. Estimated number caught in 1989 was 193 with 96 harvested. Approximate1y 52,500 Maryland strain striped bass fingerlings were stocked in 1989. In 1990, approximately 161,000 South Carolina strain fingerlings will be stocked.

Paddlefish, sauger, and walleye were present as reproducing populations before and for a period after closure of cherokee Dam. These species are now absent in the reservoir or present in greatly reduced numbers. Changes in their populations have been attributed in part to construction of the John Sevier Fossil Plant detention dam, 
which is believed to have blocked access to suitable spawning habitat. TVA has implemented a stocking program to mitigate for fish losses attributed to this reduced spawning habitat. Paddlefish stocking, initiated in 1985, was to be at a rate of 3,000 10-inch fish every other year. Actual numbers stocked have varied because of difficulties in obtaining them from paddlefish hatcheries. Assessments of stocking success are dubious because of the the difficulty in sampling the population. TWRA has closed snagging fishery for paddlefish, previously a popular method of catching them in the upper end of the reservoir.

Stocking of saugeye (walleye/sauger hybrid) resulted in a popular fishery. These hybrids entered the creel by the second year of 1 ife and showed excellent survival rate. However, production of the desired number of hybrids was unreliable from year to year. This led to a change to stock walleye, which could be produced with greater relfability. A stocking program for walleye is evaluated and negotiated between TVA and TWRA annua11y. Currently, walleye are experiencing very fast growth and a high rate of survival in Cherokee Reservoir. Two-year-old fish that were being caught in spring, 1990 were 17 to 19 inches long. Cove rotenone samples are conclucted every other year (on years when paddlefish are not stocked) to help evaluate the stocking success for these species.

Fishermen report that walleye caught in the upper end of the reservoir have an unusual taste. The cause is unknown, although a contributing factor may be ingestion of certain species of algae that are abundant at times in this reach of the reservoir. There are no restrictions or public health advisories in effect for consumption of fish from Cherokee Reservoir.

Threatened or endangered species have not been identified in Cherokee Reservoir. 'I'wo federally listed species reported in recent years in the Cherokee Dam tailwater include the threatened snail darter (Percina tanasi) and the endangered pink mucket (Lampsilis abrupta). 
Releases from Cherokee Regervolr can significantly affect downstream water quality because of seasonally low dissolved oxygen and variable temperature and flow. Significant depletion of dissolved oxygen in the hypolimnion of the reservoir, from which water is drawn for release through hydroelectric turbines, severely limits aquatic life in the tallwater. Dissolved oxygen levels drop below the $5 \mathrm{mg} / 1$ water quality standard for warmwater fish and aquatic 1 ife an average of about 22 weeks a year, below $3 \mathrm{mg} / 1$, for 12 to 15 weeks, and below $1 \mathrm{mg} / 1$ for 8 to 10 weeks.

Field personnel have noted the distinct "rotten egg" odor of hydrogen sulfide on several occasions when working below Cherokee Dam. Anaerobic decomposition of organic material in the hypolimnion of the reservoir near the dam results in the formation of hydrogen sulfide gas. No data are available to docunent sulfide concentrations in reservoir releases. However, the threshold odor concentration for sulfide is near the toxicity level reported for fish ( $2 \mathrm{ppb}$ ).

Intermittent hydroelectric releases from Cherokee Dam reduces - quality and availability of habitat creating stress for aquatic life in the tailwaters. In November 1988 TVA initiated a resérvoir releases improvement demonstration to provide a minimum flow of 325 cfs to enhance aquatic life in the tailwater. 
Cherokee Reservoir serves many uses and provides the region with many environmental and economic benefits. The water quality conditions of Cherokee Reservoir are suitable for all the uses presently identified by the Tennessee Department of Health and Environment, including domestic water supply, industrial water supply, fish and aquatic life, recreation, irrigation, and livestock watering and wildife. However, several conditions limit certain of those uses.

Low dissolved oxygen levels, in both the hypolimnion of the reservoir and in releases of that water to the stream below the dam, and fluctuations in water level in both the reservoir and tallwater are perhaps the most significant conditions affecting the uses of Cherokee Reservoir. These conditions occur frequently, are severe, and may affect several reservoir uses. Other conditions, mainly waste and chemical spills, occasionally affect the uses of the reservoir. Although many improvements have been made over the years in point source pollution control upstream, similar improvements are needed in the area of nonpoint sources. A summary of the principal conditions impairing the beneficial uses of Cherokee Reservoir are 1 isted below.

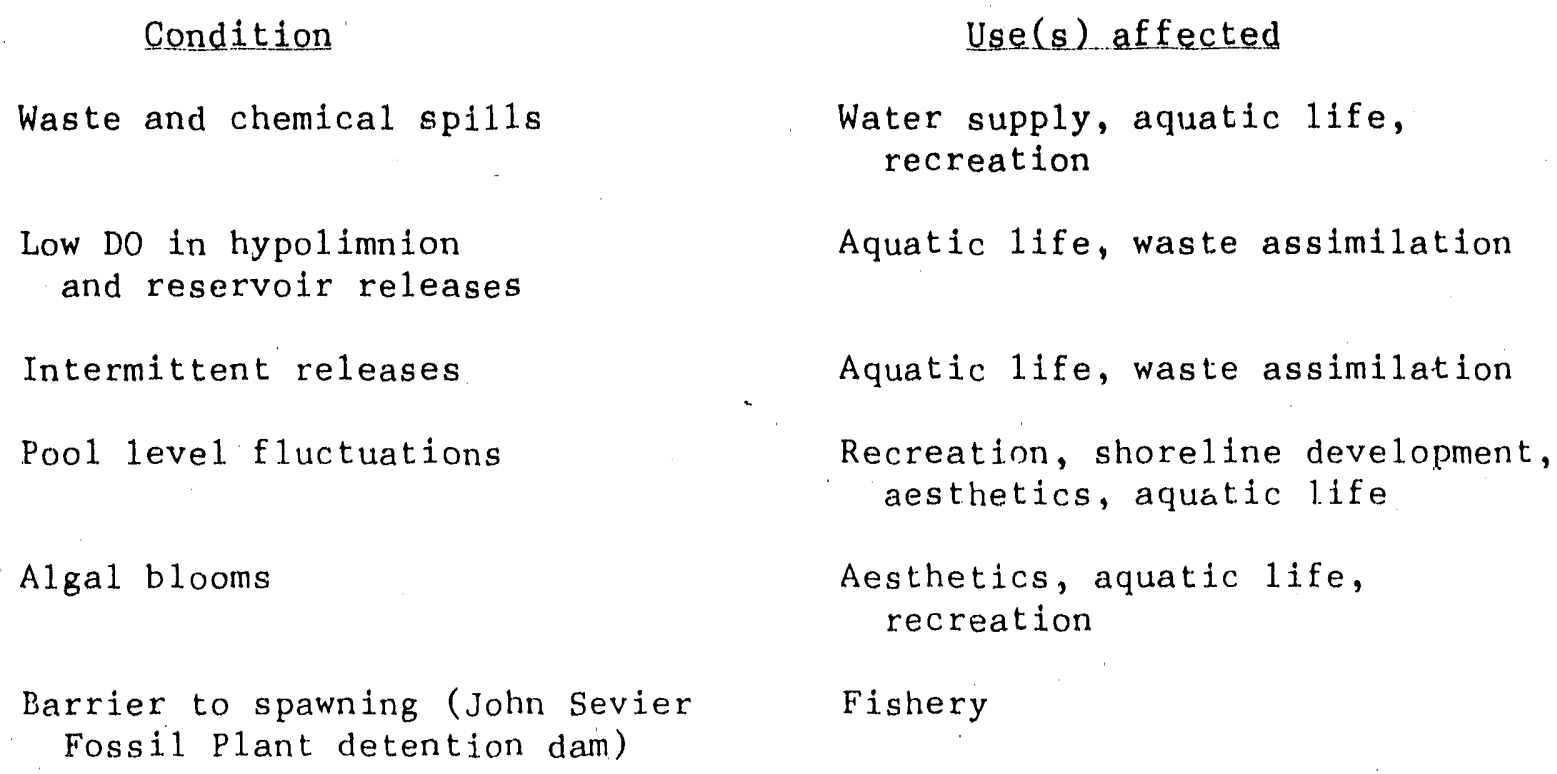


Several agencies have a part in improving and protecting the health and integrity of Cherokee Reservoir. These agencies investigate and monitor the reservoir and attempt to mitigate those conditions impairing its uses. A number of those agencies are listed below. They provide information and assistance geared to the varying needs of the region they serve.

The Tennessee Department of Health and Environment is the primary environmental rerulatory agoncy in Tennessee. It determines water use classifications, $c_{-}$il ria, and standards and issues permits for wastewater discharges. It also regulates water supplies, solid and hazardous waste, and air quality. The basin office in Knoxville, Tennessee, has primary responsibility for Cherokee Reservoir area.

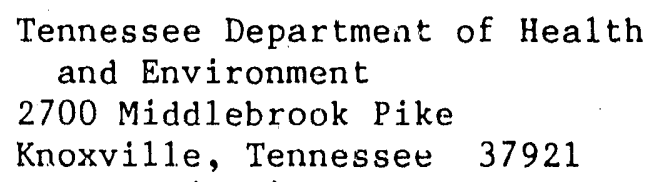

The Tennessee Valley futhority Water Resources Division manages the daily operations of Cherokee Reservoir, conducts water quality and aquatic resource monitoring and assessment programs, and develops plans for the protecting and enhancing water resources. The Land Resources Division manages TVA 1 ands and recreation sites along the reservoir and develops reservoir land-use plans.

Tennessee Valley Authority

Water Resources Division

Evans Building

Room 1W 141A

Knoxville, Tennessee 37902-1499

Phone: (615) 632-6770

\section{Tennessee Valley Authority \\ Eastern Land Resources District office 2611 Andrew Johnson Highway Morristown, Tennessee 37814 Phone: (615) 587-5600}

The Tennessee Wildlife Resources Agency is the fisheries management agency for Tennessee. It is responsible for $f$ ish and game regulations, $f$ ish stocking, boating regulations, and boat launching ramps. The regional office in Talbott, Tennessee, has responsibility for Cherokee Reservoir.

Tennessee Wildlife Resources Agency 6032 West Andrew Johnson Highway

Talbott, Tennessee 37877

Phone: (615) 587-7037 
The U.S. Department of Agriculture is responsible for soil conservation activities on farms. Various district conservationists located in county offices have responsiblility for the Cherokee Reservoir area.

The U.S. Environmental Protection Agency is responsible for the implementation of the Clean Water Act and oversees federally mandated programs managed by the states. The Region IV office in Atlanta, Georgia, is responsible for the Cherokee Reservoir area and all of the southeastern United States.

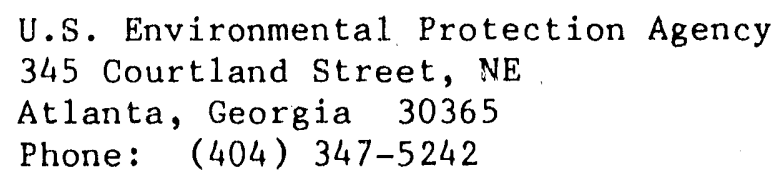

The U.S. Fish and Wild1ife Service is responsible for ensuring the protection of fish and wildife and their habitats during federally sponsored or permitted development activities and has responsibility for the identification of threatened and endangered species. The regional office in Cookeville, Tennessee is responsible for the Cherokee Reservoir area.

U.S. Fish and Wildlife Service

P.0. Box 845

Cookeville, Tennessee 38503

Phone: (615) 528-6481 
Carden, D.M. and L.B. Oxendine. 1990. "Water Resources Issues Analysis: North Fork, South Fork Below Ft. Patrick Henry Dam, and the Mainstem Holston River Basins," Draft Report, Tennessee Valley Authority, Water Quality Department.

Cox, J. 1986. "South Fork Holston Basin Rehabilitation Project - Water Resources Issues Analyses," Report No. TVA/ONRED/AWR 87/4, Tennessee Valley Authority, Division of Services and Field Operations.

Heuer, J. J. and D. A. Tomljanovich. 1980. A synopsis of fisheries investigations on Cherokee Reservoir: 1941-1979. Division of Water Resources, Office of Natural Resources, Tennessee Valley Authority. Technical Report No. WR-40-1-80.1. $43 \mathrm{pp}$.

Peterson, D. C. and D. E. Lane. 1988. "Annual Reservoir Report 1988 for Cherokee Reservoir," Tennessee Wild1ife Resources Agency.

Peterson, D. C. and D. E. Lane. Undated. 1989 Cherokee Reservoir annual report. Tennessee Wildlife Resources Agency. 138 pp.

P1acke, J. 1983. "Trophic Status Evaluation of TVA Reservoirs," Report No. TVA/ONRED/WR-8317, Tennessee Valley Authority, Division of Services and Field Operations.

Poppe, W., et al. 1980. "Eutrophication Analysis of Cherokee Reservoir," Report No. WR-50-25-80.01, Tennessee Valley Authority .

Tennessee Department of Health and Environment. 1988. "The Status of Water Quality in Tennessee. 305(b) Report, Office of Water Management, Nashville, Tennessee.

Tennessee Valley Authority. "Improving Reservoir Releases," Annual Reports 1981, 1982, 1983, 1984, and 1987, Office of Natural Resources and Economic Development.

Tennessee Valley Authority. 1984. "Water Quality Management Plan for Cherokee Reservoir," Report No. TVA/ONRED/WRQ-84/1, Division of Air and Water Resources.

Tennessee Valley Authority. 1990. "Tennessee River and Reservoir System Operation and Planning Review." Draft Environmental Impact Statement. Tennessee Valley Authority, Knoxville, Tennessee. 


\section{ACKNOWLEDGMENTS}

This work was funded by Federal appropriations to the Tennessee Valley Authority (TVA) for water resources management. This report was prepared by members of a project team of the Water Resources Division of TVA with other TVA staff assisting.

Your comments and suggestions are important to us! They help us better meet the information needs of reservoir users. Comments, suggestions, and requests for additional copies of this report should be directed to:

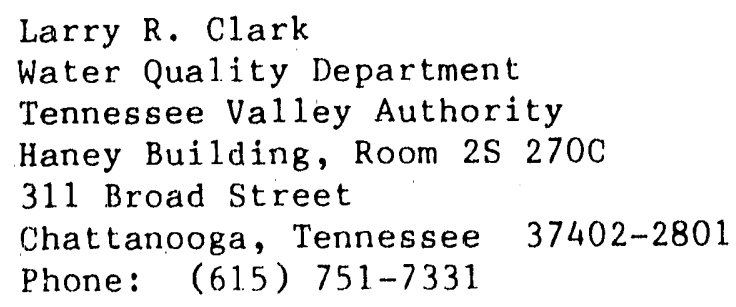

TVA is an equal opportunity and affirmative action employer. TVA also ensures that the benefits of programs receiving TVA financial assistance are available to all eligible persons regardless of race, color, sexy national origin, handicap, or age. 

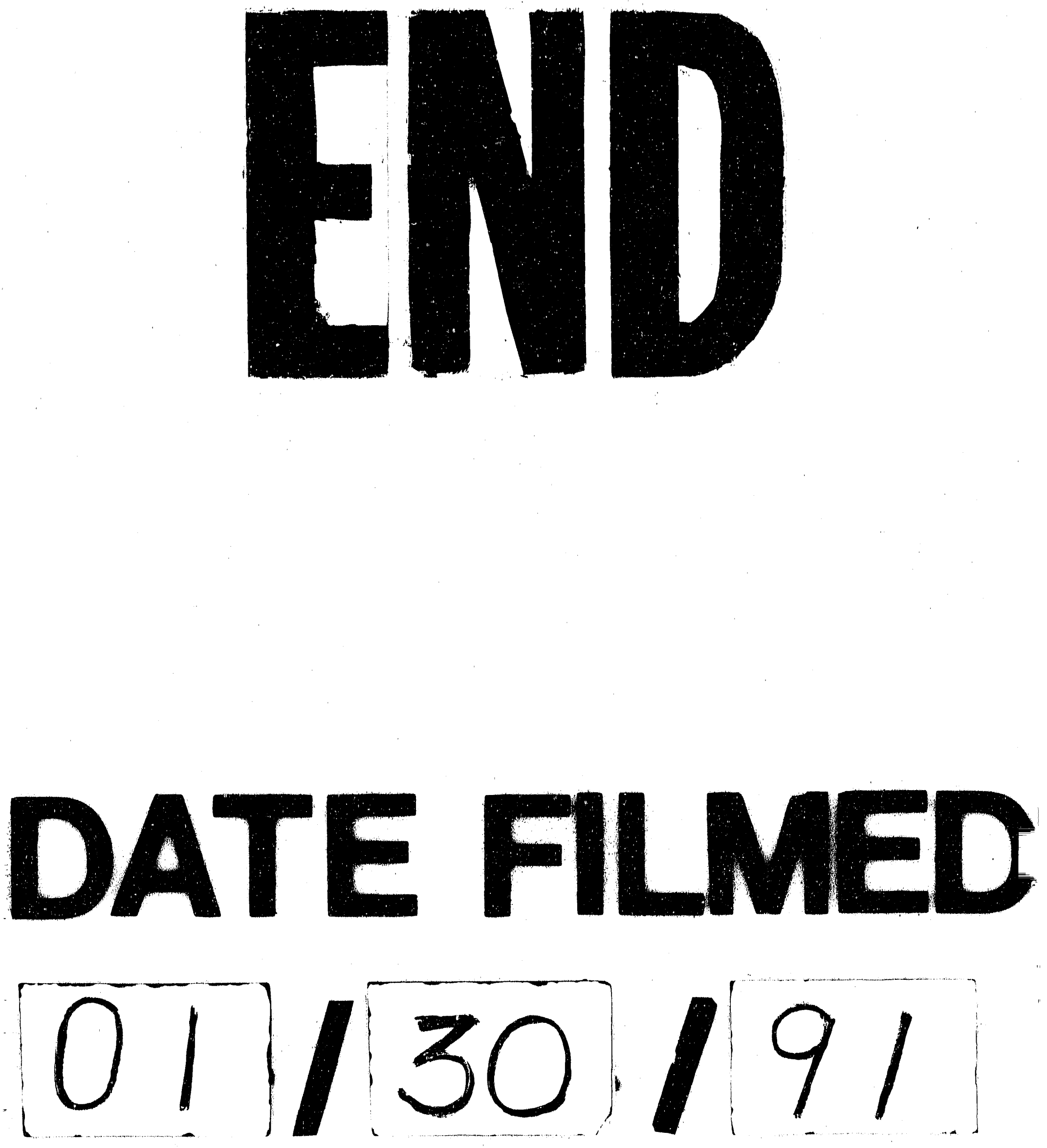
